\title{
Sustainable income generation of the farmers through pig farming: A case study in Terai region of West Bengal
}

\author{
G. Das ${ }^{1 *}$, D.K. Hajra ${ }^{2}$, R.D. Mukherjee ${ }^{1}$, S. Hembram ${ }^{1}$ and B. Roy ${ }^{1}$
}

${ }^{1}$ Cooch Behar Krishi Vigyan Kendra, ${ }^{2}$ Department of Agronomy, Faculty of Agriculture, Uttar Banga Krishi Viswavidyalaya, Pundibari, Cooch Behar, West Bengal.

"Corresponding author email id: ganesh.ext@gmail.com

Journal of Livestock Science (ISSN online 2277-6214) 12: 241-245

Received on 27/5/21; Accepted on 12/7/21; Published on 28/7/21

doi. 10.33259/JLivestSci.2021.241-245

\begin{abstract}
In India, majority of pig farmers are from backward section of population and follow traditional small-scale subsistence production system for their livelihood and food security. Pig farming may be a sustainable income generation way of the farmers in terai region of West Bengal due to availability of market. It was found from the survey that farmers of this region were perceived different constraints on pig farming. The major constraints were shortage of improved breed, lack of marketing network, credit linkage, knowledge and skill. Based on the above situation Krishi Vigyan Kendra, Cooch Behar conducted trainings and experimental programme on scientific pig farming from 2017 to 2019 in terai region of West Bengal. A case study was conducted to know impact of the experimental programme under different socio economic conditions. It was found from the study that annual income, house type, assets, employment generation \& credit orientation of the farmers were increased after adoption of scientific pig farming technology. It was found from the study that net income of the farmers was more in case of Large White Yorkshire farming (Rs. 63000-75000) followed by Ghungroo pig farming (Rs. 40000-43000).
\end{abstract}

Keyword: Training; Demonstration; sustainable income generation; Ghungroo pig; Large White Yorkshire. 


\section{Introduction}

World livestock production is going to be more and more complicated in order to improve efficiency needed to supply the rising demand for animal protein. Pig farming contributes in many ways to improve the sustainable income generation of marginal small farmers. Pig products provide for high value animal protein, the meat is easy to dress and has superior curing and storage qualities. Additional income is earned from the sale of animals and importantly from their products. This additional income can be used to invest in farm assets, pay for educational cost and health treatments (Klass, 2011). This is a well-accepted notion that the smallholder livestock production systems improve livelihood and food security for the poorest people. In addition to protein for human consumption, pigs are often one of the main sources of cash income in rural areas and provide manure for cropping. Swine rearing promotes better self-reliance along with greater food security to urban households (Mougeot, 2000). The importance of low protein and high protein (soyabean) diets on the nitrogen balance and productivity of pigs and additives like Lithiun ascorbate to reduce stress for improvement of pork quality has been well described (Niyazov and Ostrenko, 2020; Ostrenko et al 2020; Tedtova et al). Work has been initiated globally on application of modern technologies like Crispr/Cas9 on pig breeding (Tinh et al 2020).

In India, majority of pig farmers are from backward section of population and follow traditional small-scale subsistence production system for their livelihood and food security. As per 19th Livestock census, out of the total 10.294 million pig population, the exotic/crossbred was 2.456 million while indigenous pigs were 7.837 million. Highest share of country's pig population was found in Assam (15.89\%) followed by Uttar Pradesh (12.96\%), Jharkhand $(9.35 \%)$, Bihar $(6.31 \%)$ and West Bengal $(6.30 \%)$. Despite its demand in the local market, the country has remained in undeveloped stage in swine production mostly due to social hindrances associated with the pig. The traditional pig farmers follow subsistence driven production system characterized by unhygienic production and low productivity. As per the report of the Department of Agricultural Research and Education (DARE), (2012-13), domestic production of pork was $0.45 \mathrm{mt}$ with an average meat yield of about $39 \mathrm{~kg} /$ animal, which is lower than the world average (79 kg/animal). Pig production, among other species has a higher potential to contribute to more economic gain due to the pigs have higher fecundity, higher feed conversion efficiency, early maturity, shorter generation interval and relatively smaller space requirement. Apart from providing meat, it is also a source of bristles and manure. Pig farming provides employment opportunities to seasonally employed rural farmers and supplement income to improve their living standards.

Cooch Behar district of West Bengal is situated bordering to Assam, the gateway to NE states which harbours the major part of the pig population of the country. Cooch Behar and adjoining districts including Alipurduar and Jalpaiguri is a part of special geographical location known as Dooars, which shares border with Bhutan and Bangladesh. For a considerable portion of the population $(>50 \%)$ belongs to backward section in this part of the state. Pig production which contributes a significant part of rural economy and traditional culture is very common the region. Visit in the locality is sufficient to enumerate some of the basic problems in pig husbandry practices in the locality. Unavailability of quality germplasm, lack of knowledge and skill for scientific production, less credit orientation are some of the basic hindrances associated with this enterprise. Undertaking more training, demonstration and technology intervention programmes on improved pig farming for the greater benefit of the farming community have been recommended by researchers (Hemchandra et al., 2017, Tsado et al., 2014) and extension functionaries for encouraging small farmers for scientific pig production with the aim to enhance production, productivity and livelihood security. Keeping this in view Cooch Behar KVK conducted different types of training and demonstration programme on pig farming. The present study was undertaken to find out the sustainable income generation of the farmers through pig farming under the guidelines of KVK, Cooch Behar.

\section{Materials and Methods}

A ground level of survey was conducted in different villages of Cooch Behar District for to know the status of pig farming. It was found from the survey that training \& demonstration were need for development of pig farming in Cooch Behar District. Cooch Behar Krishi Vigyan Kendra arranges 3 numbers of training programme on scientific method of pig farming during 2017-18 (Table 1). Total 87 participants were participated in the programme. The programme was conducted with the help of University scientist, block livestock development officer \& veterinary doctor. Different training method \& tools were used for development of knowledge, skill and attitude of the farmers. It was found from the study that knowledge, skill and attitude of the farmers were increases after the training programme. Trainees were regularly monitored through field visit, phone call and use of different e-resources. It was observed from the study that majority of the trainees started pig farming with the technical help of KVK. But it was observed that knowledge and skill distortion rate of the trainees were high during 
implementation of the pig farm. On the basis of study an experimental trial was conducted on scientific method pig farming (breed Ghugroo, Large White Yorkshire) in different block of Cooch Behar district (Mathabhanga-II, Cooch Behar-II, Cooch Behar-I and Tufanganj-II Block). 60 numbers of Ghungroo piglets \& 10 numbers of Large White Yorkshire piglets were distributed among the 20 number of interested farmers for experimental purpose. Regular vaccinations were provided from Krishi Vigyan Kendra, Cooch Behar. A details case study was conducted on 5 numbers of pig farmers $\left(\mathrm{F}_{1}, \mathrm{~F}_{2}, \mathrm{~F}_{3}, \mathrm{~F}_{4}\right.$ and $\left.\mathrm{F}_{5}\right)$ selected randomly from 20 numbers of farmers (sampling frame). The study was conducted from September, 2016 to March, 2020. The work is done following steps

a) Benchmark survey: Identification of training need \& demonstration programme (Year: 2016)

b) Data analysis \& interpretation

c) Conducting the training programme with the help of University and KVK scientist, block livestock development officer \& veterinary doctors (Year: 2017-18).

d) Evaluation of training (knowledge, skill, attitude, adoption)

e) Demonstration of improved Ghungroo \& Large White Yorkshire piglet breed under different conditions (Year: 2017-18, 2018-19 \& 2019-20).

f) Evaluation of the demonstration for check of economic sustainability of breed and socio-economic development of farmers (Year: 2019-20).

g) Impact analysis of the demonstration \& the farmers' feedback (Year: 2019-20).

Table no. 1: Training on pig farming, year 2017

\begin{tabular}{|c|c|c|c|c|c|c|c|}
\hline Sl. No. & Year & \multicolumn{7}{|c|}{ Participant } \\
\hline & & SC & ST & Others (GEN/OBC) & Male & Female & Total \\
\hline 1 & 2017 & 12 & 14 & 4 & 30 & 0 & 30 \\
\hline 2 & 2017 & 8 & 17 & 0 & 25 & 0 & 25 \\
\hline 3 & 2017 & 14 & 12 & 6 & 26 & 6 & 32 \\
\hline \multicolumn{2}{r|}{ Total } & 34 & 43 & 10 & 81 & 6 & 87 \\
\hline A & \% Participation & 39.08 & 49.42 & 11.50 & 93.10 & 6.90 & 100 \\
\hline B & Adoption & 20 & 38 & 10 & 66 & 2 & 68 \\
\hline C & \% Adoption & 58.82 & 88.37 & 100 & 81.48 & 33 & 78.16 \\
\hline
\end{tabular}

\section{Results and Discussion}

It is found from the study that (Table 1) ST farmers (49.42\%) were more participated in training programme followed by SC (39.08\%) \& Others (GEN/OBC) $(11.50 \%)$ category farmers. It is revealed from the study that ST farmers were more interested in pig farming followed by SC \& GEN/OBC category farmers. This finding is in line with the study found by Seth et al. (2016). It is also found from the study that adoption percentage of pig farming technology was more in case of GEN/OBC (100\%) category farmers followed by ST (88.37\%) and SC $(58.82 \%)$ category farmers. It is observed from the table 1 that male farmers were more participated (93.10\%) in the training programme followed by female farmers $(6.90 \%)$ and adoption percentage of pig farming was more by male farmers $(81.48 \%)$ followed by female farmers $(33 \%)$.

The distribution of technology ( $T_{1}$ to $T_{5}$ ) according to the socio-economic condition of the farmers is depicted in the table 2. It is shown from the table 2 that five numbers of technological options were experimented in the farmers' field. It is exposed (table no. 2) from the study that majority farmers were marginal farmers $\left(\mathrm{F}_{1}, \mathrm{~F}_{2}, \mathrm{~F}_{3}\right.$, $\mathrm{F}_{5}$ ) followed by small farmer $\left(\mathrm{F}_{4}\right)$. It is also found from the study that majority of the farmers were primary school pass $\left(F_{1}, F_{3}, F_{5}\right)$ followed by high school pass $\left(F_{2}, F_{4}\right)$.

It is found from the study that (Table 3 ) annual income the $F_{1}$ farmers (Rs. 210000) was more after pig farming, followed by $F_{2}$ (Rs. 96000), $F_{4}$ (Rs. 70000), $F_{5}$ (Rs. 50000) and $F_{3}$ (Rs. 40000) farmers. It is revealed from the study that Technology option 1 (T1) was more profitable followed by technology option $2\left(\mathrm{~T}_{2}\right)$, technology option $4\left(\mathrm{~T}_{4}\right)$, technology option $5\left(\mathrm{~T}_{5}\right)$ and technology option $3\left(\mathrm{~T}_{3}\right)$. But it is also observed that socio-economic condition of the $F_{1}$ farmer was high followed by $F_{2}, F_{4}, F_{5}$ and $F_{3}$ farmer. So it is revealed that technology option of pig farming and basic socio-economic conditions influenced the annual income of the farmers. It is observed from the study that house type of $F_{3}$ and $F_{5}$ farmer and assets of $F_{3}, F_{4}$ and $F_{5}$ farmer were change after the adoption of the pig farming practices. It is also found from the table 3 that credit orientation $\left(\mathrm{F}_{1} \& \mathrm{~F}_{4}\right)$ \& employment generation $\left(\mathrm{F}_{1}, \mathrm{~F}_{2}\right)$ of the farmers were positively increases. It is revealed from the study that (Table. 4) benefit cost ratio was more in case of Large White Yorkshire farming (3.73-3.92) followed by Ghungroo pigs farming (3.15-3.22). It is also exposed from the study $\left(\mathrm{F}_{2}\right)$ that (Table $\left.4 \& 5\right)$ net income of the farmers were more in case of Large White Yorkshire farming (Rs.63000-75000) followed by Ghungroo pig farming (Rs. 40000-43000). 
Das et al 2021/ J. Livestock Sci. 12: 241-245

Table 2: Technology option according to the socio economic conditions of the farmers

\begin{tabular}{|c|c|c|c|c|c|}
\hline Name of the Farmer & $\mathrm{F}_{1}$ & $\mathrm{~F}_{2}$ & $\mathrm{~F}_{3}$ & $\mathrm{~F}_{4}$ & $\mathrm{~F}_{5}$ \\
\hline Caste & $\mathrm{SC}$ & $\mathrm{SC}$ & ST & ST & ST \\
\hline Land holding (acre) & 2.0 & 1.5 & 1.6 & 5.0 & 1.5 \\
\hline $\begin{array}{l}\text { Educational } \\
\text { qualification }\end{array}$ & Primary school pass & Higher secondary pass & Primary school pass & Higher secondary pass & Primary school pass \\
\hline Technology & $\begin{array}{l}\text { Two numbers of Large White } \\
\text { Yorkshire breed (male \& } \\
\text { female), Pucca shelter, good } \\
\text { drainage, regular vaccination } \\
\text { facility, good quality feed } \\
\text { supply }\left(\mathrm{T}_{1}\right)\end{array}$ & $\begin{array}{l}\text { Two numbers of Large White } \\
\text { Yorkshire breed (male and } \\
\text { female), Mixed shelter, with } \\
\text { medium drainage \& regular } \\
\text { vaccination facility, good } \\
\text { quality feed supply }\left(\mathrm{T}_{2}\right)\end{array}$ & $\begin{array}{l}\text { Two numbers of Ghungroo } \\
\text { pig breed (male and female), } \\
\text { temporary shelter, no } \\
\text { drainage facility, regular } \\
\text { vaccination, good quality feed } \\
\text { supply }\left(\mathrm{T}_{3}\right)\end{array}$ & $\begin{array}{l}\text { Two numbers of Ghungroo pig } \\
\text { breed (male and female), Mixed } \\
\text { Shelter, good drainage vaccination } \\
\text { and good quality feed supply }\left(\mathrm{T}_{4}\right)\end{array}$ & $\begin{array}{l}\text { Two numbers of } \\
\text { Ghungroo pig breed } \\
\text { (male and female), } \\
\text {, temporary shelter, } \\
\text { good drainage, regular } \\
\text { vaccination facility, } \\
\text { good quality feed supply } \\
\left(\mathrm{T}_{5}\right)\end{array}$ \\
\hline
\end{tabular}

Table 3: Socio economic impact of the experimental trial

\begin{tabular}{|c|c|c|c|c|c|c|c|c|c|c|c|c|c|c|c|c|}
\hline \multirow{2}{*}{\multicolumn{2}{|c|}{ Variables }} & \multicolumn{3}{|c|}{$\mathrm{F}_{1}$} & \multicolumn{3}{|c|}{$\mathrm{F}_{2}$} & \multicolumn{3}{|c|}{$\mathrm{F}_{3}$} & \multicolumn{3}{|c|}{$\mathrm{F}_{4}$} & \multicolumn{3}{|c|}{$\mathrm{F}_{5}$} \\
\hline & & Before & After & Increase & Before & After & Increase & Before & After & Increase & Before & After & Increase & Before & After & Increase \\
\hline 1 & $\begin{array}{l}\text { Annual } \\
\text { Income (Rs.) }\end{array}$ & 150000 & 360000 & 210000 & 110000 & 206000 & 96000 & 90,000 & 130000 & 40000 & 110000 & 18,0000 & 70000 & 90,000 & $\begin{array}{l}14000 \\
0\end{array}$ & 5000 \\
\hline 2 & House type & Pacca & Pacca & - & Pacca & Pacca & - & Kachha & Mixed & Mixed & Mixed & Pacca & Pacca & Kaccha & Mixed & Mixed \\
\hline 3 & Assets & \begin{tabular}{|l}
$\mathrm{TV}$, \\
Motorcycle
\end{tabular} & \begin{tabular}{|l|} 
Not \\
Change
\end{tabular} & & $\begin{array}{l}\mathrm{TV}, \\
\text { Motorcycle }\end{array}$ & $\begin{array}{l}\text { Not } \\
\text { change }\end{array}$ & & $\mathrm{TV}$ & $\begin{array}{l}\text { TV, } \\
\text { Motorcycle }\end{array}$ & Motorcycle & \begin{tabular}{|l|}
$\mathrm{TV}$, \\
Tractor
\end{tabular} & $\begin{array}{l}\text { TV, Fridge } \\
\text { Tractor }\end{array}$ & Fridge & - & TV & TV \\
\hline 4 & $\begin{array}{l}\begin{array}{l}\text { Employment } \\
\text { generation }\end{array} \\
\end{array}$ & - & 1 & 1 & - & 1 & 1 & - & - & - & - & - & & - & - & - \\
\hline 5 & $\begin{array}{l}\text { Credit from } \\
\text { bank }\end{array}$ & & Yes & & - & - & & - & - & - & & Yes & & - & - & - \\
\hline
\end{tabular}

Table 4: Economic analysis of Large White Yorkshire and Ghungroo pig breed

\begin{tabular}{|c|l|l|l|l|l|l|l|l|}
\hline \multicolumn{1}{|c|}{ Breed } & $\begin{array}{l}\text { Total Cost* } \\
\text { (Rs.) }\end{array}$ & $\begin{array}{l}\text { Profit from } \\
\text { meat (Rs.) }\end{array}$ & $\begin{array}{l}\text { Number of } \\
\text { piglet in year }\end{array}$ & $\begin{array}{l}\text { Piglet price } \\
\text { (Rs.) }\end{array}$ & $\begin{array}{l}\text { Income from } \\
\text { piglet (Rs.) }\end{array}$ & $\begin{array}{l}\text { Total income } \\
\text { (Rs.) }\end{array}$ & $\begin{array}{l}\text { Net income } \\
\text { (Rs.) }\end{array}$ & $\begin{array}{l}\text { Benefit Cost } \\
\text { Ratio }\end{array}$ \\
\hline Ghungroo pig & $18000-20000$ & $34000-36000$ & $8-9$ & 3000 & $24000-27000$ & $58000-63000$ & $\begin{array}{l}40000- \\
43000\end{array}$ & $3.15-3.22$ \\
\hline $\begin{array}{l}\text { Large White } \\
\text { Yorkshire }\end{array}$ & $23000-25000$ & $46000-50000$ & $10-12$ & 4000 & $40000-48000$ & $86000-98000$ & $\begin{array}{l}63000- \\
75000\end{array}$ & $3.73-3.92$ \\
\hline
\end{tabular}


Table no. 5: Cost Breakup (Rs.) of large white York shire and Ghungroo pig breed

\begin{tabular}{|l|c|c|c|c|}
\hline \multicolumn{1}{|c|}{ Breed } & Piglet cost (Rs.) & feed (Rs.) & $\begin{array}{c}\text { Others cost (Rs.)(Labour, electric, } \\
\text { Medicine, Shelter) }\end{array}$ & Mortality rate \\
\hline Ghungroo Pig & $2500-3000$ & $3500-5000$ & $1500-2000.00$ & $3 \%$ \\
\hline Large White Yorkshire & $4000-4500$ & $3500-5000$ & $1500-2000.00$ & $2 \%$ \\
\hline
\end{tabular}
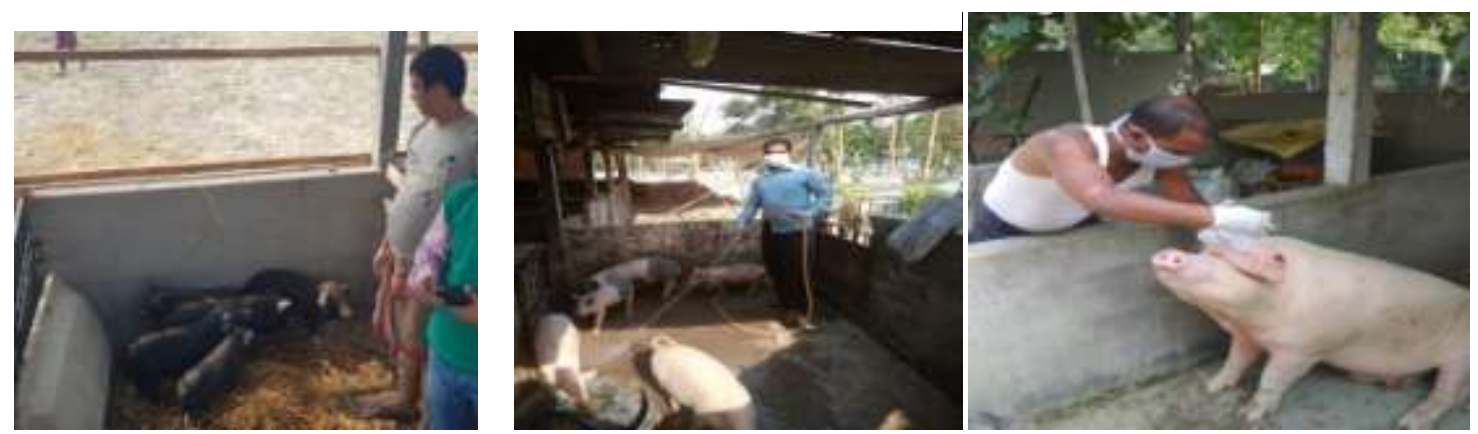

Conclusion It is revealed from the study that ST farmers were more interested in pig farming followed by SC \& GEN/OBC category farmers but in case of technology adoption it is observed that adoption percentage of GEN/OBC category farmers were more followed by SC and ST category farmer. It is revealed from the study that male farmers were more interested in pig faming than female farmer. It is exposed from the study that marginal and less educated farmers were more interested in pig farming. It is concluded from the study that both Ghungroo and Large White Yorkshire are profitable which is influenced the farmers socio-economic condition and additional employment generation. From the comparative point of view it is observed that Large White Yorkshire is more profitable than Ghungroo breed. It is concluded from the study that scientific pig farming is a way of sustainable income generation of the farmers.

Acknowledgement: ICAR-ATARI, Kolkata and ICAR-IGFRI, Jhansi

\section{References}

1) Hemchandra, S., Saud, R.K., Kalita, D.N. and Kalita, S. (2017) Impact of piggery training on the income level and profit of pig farmers- A case study in Kamrup district of Assam (India). Indian Journal of Agriculture Research 51(6): 619-622.

2) Klass, D. (2011). Pig for prosperity, Diversification booklet number 15, FAO, Rome.

3) LIVESTOCK CENSUS (2012), All India Report, Ministry of Agriculture Department of Animal Husbandry, Dairying and Fisheries Krishi Bhawan, New Delhi

4) Mougeot, L. J.A. (2000). Auto suffisancealimentairedans les villes: l'agricultureurbainedans les pays du Sud à l'ère de la mondialisation. In M. Koc, R. Macrae, L.J.A. Mougeot, \& J. Welsh (Eds.), Armer les villescontre la faim : systèmesalimentairesurbains durables (pp.2-11). Centre de Recherches pour le Développement International, Ottawa, Canada.

5) Niyazov N.S.-A., Ostrenko K.S. 2020. Effect of low-protein diets on the nitrogen balance and productivity of pigs. Journal of Livestock Science 11:106-109

6) Ostrenko K.S., Ovcharova A.N., Sofronova O.V. 2020. Use of Lithium Ascorbate to reduce stress for improvement in pork quality. Journal of Livestock Science 11: 95-100

7) Seth, P.; Chander, M.; Singh, N.; Kumari, R.; Basunathe, V. K.; and Das, G. (2016). Caste and Societal Movement towards Adoption of Cross Breeding Technology in Piggery: A Case of 'T\&D' Pig breed in eastern India. International Journal of Science, Environment, and Technology, 5 (6), pp. $3914-3921$.

8) Tedtova V.V., Temiraev R.B., Kairov V.R., Dzhaboeva A.S., Yurina N.A., Temiraev K.B., Baeva Z.T., Bobyleva L.A., Zagaraeva E.F., Efendiev B.S. 2020. Effect of soybean feeding on productivity of sows, growth of piglets and quality of pork. Journal of Livestock Science 11: 20-25.

9) Tinh N.H., Bui A.P.N., Tran T.T.H. 2020. Crispr/Cas9 and its current application status on pig breeding. Journal of Livestock Science 11:110-115.

10) Tsado, J. H.; Ojo, M. A.; and Ajayi, O. J. (2014). Impact of training the trainers programme on rice farmers income and welfare in north central Nigeria. Journal of Advanced Agricultural Technologies, 1(2):157-160. 